\title{
BCR for Seed and Fibre Production with Seed and Cutting Treatments at Different Sowing Methods at JAES and KRS, BJRI in 0-9897 Variety
}

\author{
S. M. A. Haque ${ }^{1, *}$, I. Hossain ${ }^{2}$, M. A. Rahman ${ }^{2}$ \\ ${ }^{1}$ Department of Plant Pathology, Pest Management Division, Bangladesh Jute Research Institute, Bangladesh \\ ${ }^{2}$ Department of Plant Pathology, Bangladesh Agricultural University, Bangladesh
}

Copyright (C) 2015 by authors, all rights reserved. Authors agree that this article remains permanently open access under the terms of the Creative Commons Attribution License 4.0 International License

\begin{abstract}
Line sowing method had less cost of seed production and more BCR than top cutting method. In case of line sowing, for seed production maximum BCR 1.30 was observed with BAU- Biofungicide treated seeds and lowest BCR 1.16 under control treatment. For fibre production, highest BCR 2.71 was observed with BAU- Biofungicide treated seeds and lowest BCR 1.29 was under control treatment. In case of top cutting, highest BCR 1.13 was recorded under BAU- Biofungicide treated cuttings and lowest 1.02 was under control treatment. So, line sowing method was found most suitable compared to top cutting method for production of quality healthy jute seeds with maximum BCR.
\end{abstract}

Keyword BCR, Seed Treatment, Cutting Treatment, Sowing Method, Seed Yield and Fibre Yield, O-9897

\section{Introduction}

Jute is one of the major cash crops of Bangladesh. Its influence on ecology and economy is so intimate that the effects are significantly related to the agro-ecology and the socio-economic life of the people. The jute crop also greatly improves the soil fertility status by incorporating organic matter to the soil through decomposition of shaded leaves and plant residues and helps in breaking plough-pans through its long taproots. Also, jute and jute goods have been recognized as being friendly to the environment. Jute is mostly grown in the Indo-Bangladesh region and in some countries of Southeast Asia. Among the jute growing countries of the world, Bangladesh was second position in respect of production (7). The land and climatic conditions of Bangladesh are congenial for the production of high quality jute. In Bangladesh, about 0.709 million hectares of land was under jute cultivation and the total yield was 8.40 million bales $(1,2)$. Bangladesh annually needs about 4000 metric tons of jute seeds of which only $12-15 \%$ is produced and supplied by the Bangladesh Agricultural Development Corporation (BADC) (10). The rest of the seeds, about $85 \%$ or more of the requirement, are produced and managed by farmers' (5). Seed is the basic input for crop production. Quality seed of a variety is the key to better crop establishment and better yield. The conventional method of jute seed production is not enough at all to meet the demand of the farmer. Jute in Bangladesh is not grown for seed purpose as it requires long time from March- December and this hampers cultivation of transplant amon rice and rabi crops. The farmers usually keep a small portion of crop at one corner or any suitable place of the field to produce seed and rest of the crop is harvested for fibre. This traditional system of seed production is characterized by low yield and poor quality seed. So, for highest seed production farmers' top cutting method, at present BADC is the only public sector producing certified jute seed in their own firm as well as through contract growers. BADC can not meet up more than $10 \%$ of the total requirement. To overcome the situation to some extend since last 5-6 years BJRI has been supplying $100 \mathrm{gm}$ of quality seed to individual farmer, free of cost through Agricultural Extension Directorate to produce jute seed in late sowing method and to promote the exchange of seed among the farmers. For this approach BJRI annually is distributing $300-400 \mathrm{~kg}$ of quality jute seed to the farmers.

\section{Materials and Methods}

\section{Experimental Sites and Period}

The experiments were conducted in the field of Jute Agriculture Experimental Station (JAES), Manikgonj and Kishoregonj Regional Station (KRS), Kishoregonj of BJRI. The experiments were conducted during the period April 2012 to January 2013.

\section{Varieties Used}

O-9897 


\section{Cultivation Method}

i) Line sowing method

ii) Top cutting method

\section{Seed Management}

i) Seed treated with Provax-200 WP $(0.4 \%$ of seed weight)

ii) Seed treated with BAU- Bio fungicide @ 3\% of seed weight (4)

iii) Control (Untreated)

\section{Cutting Management}

i) Cutting treated with Dithane M-45

ii) Cutting treated with BAU- Bio fungicide @ 2\% of water (4)

iii) Control (Untreated)

\section{Application of Fertilizers}

During final land preparation Urea $60 \mathrm{~kg}$, Triple Super Phosphate $50 \mathrm{~kg}$ and Muriate of Potash $25 \mathrm{~kg}$ per hectare were applied (8 and 9). After 15-20 days of seed germination first top dressing with the urea @ 60 kg and again another 15 days later of first top dressing, the $2^{\text {nd }}$ top dressing was given with $60 \mathrm{~kg}$ per hectare. Top dressing of urea was done very carefully so that it will not come in contact with the plant parts. To meet sulphur and zinc deficiency, gypsum and zinc oxide@ 95 kg and 5 kg per hectare were applied (8 and 9).

\section{Experimental Design}

The experiments were conducted following Randomized Block Design (RCBD) having three replications. The size of the unit plot was $10 \mathrm{~m}^{2}(5 \mathrm{~m} \mathrm{x} 2 \mathrm{~m})$ and the distance between plots and replications were $1.0 \mathrm{~m}$ and $1.0 \mathrm{~m}$, respectively.

\section{Soil Characteristics and Nutrient Status}

The Soil characteristics and nutrient status of the two experimental stations (JAES, Manikgonj and KRS, Kishoregonj) are shown in Table 1.

\section{Calculation of Benefit Cost Ratio (BCR)}

\section{BCR for Seed Production with Line Sowing and Top Cutting Methods}

Benefit Cost Ratio of line sowing and top cutting were calculated for production of quality healthy jute seeds to determine the economically most suitable method. The Benefit Cost Ratio was determined by using the finding of the study that conducted at Jute Agriculture Experimental Station (JAES), Manikgonj, and Kishoregonj Regional Station (KRS), BJRI. Different operational costs required for plowing, laddering, thinning, fertilizer applications, harvesting, hoeing, top cutting, leaf tearing, cutting plantation, gap filling, threshing, winnowing and drying of seeds for production of seeds/ hectare of land were calculated for both capsularis and olitorius based on present market price (Tables 2 and 3). A comparative study on cost and return among these seed production methods were done using the variables- Cost, Gross Benefit, Net Return and Benefit Cost Ratio.

\section{Cost (Variable)}

Variable cost is equal to total cost minus fixed cost (Dillon and Hardaker, 1993)

\section{Gross Benefit (GB)}

Gross Benefit of seed yield was calculated by multiplying the amount of seed yield by the corresponding market price (11).

\section{Net Return (NR)}

The Net Return was achieved by deducting the variable expenses from the Gross Benefit. Total cost (only variable cost) was deducted from the gross income of seed yield (3)

Table 1. Soil characteristics and nutrient status of the two experimental locations in 2012

\begin{tabular}{|c|c|c|c|c|c|c|c|}
\hline \multirow{2}{*}{ Experimental location } & AEZ & \multicolumn{3}{|c|}{ Soil characteristics } & \multicolumn{2}{c|}{ Nutrient status } \\
\cline { 2 - 7 } & Land type & Soil type & pH & $\%$ OM & P (ppm) & K (meq/100) & \\
\hline $\begin{array}{c}\text { Jute Agriculture } \\
\text { Experimental Station } \\
\text { (JAES), Manikgonj, } \\
\text { BJRI }\end{array}$ & $\begin{array}{c}\text { Brahmaputra and } \\
\text { Jamuna Flood } \\
\text { Plain (AEZ-7) }\end{array}$ & $\begin{array}{c}\text { Medium } \\
\text { land }\end{array}$ & $\begin{array}{c}\text { Sandy and } \\
\text { Silty }\end{array}$ & 6.69 & 1.79 & 0.35 \\
\hline $\begin{array}{c}\text { Kishoregonj Regional } \\
\text { Station (KRS), BJRI }\end{array}$ & $\begin{array}{c}\text { Old Brahmaputra } \\
\text { Flood Plain } \\
\text { (AEZ-9) }\end{array}$ & $\begin{array}{c}\text { Medium } \\
\text { land }\end{array}$ & Loam & 6.11 & 1.24 & 0.138 \\
\hline
\end{tabular}


Table 2. Cost of seed and fibre production per hectare of land following line sowing method at 2012

Input cost: i) Non-material cost:

\begin{tabular}{|c|c|c|c|}
\hline $\mathrm{Sl}$ & Items & Required amount/ha & Total cost (Tk) \\
\hline 1 & Labour cost (Plowing + Laddering) & 13 & $13 \times 180=2340.00$ \\
\hline & Labour cost (Grass cleaning and levelling) & 13 & $13 \times 180=2340.00$ \\
\hline 2 & Labour cost (Lay out prepared + line sowing) & 8 & $8 X 180=1440.00$ \\
\hline 3 & $1^{\text {st }}$ weeding & 28 & $28 \times 180=5040.00$ \\
\hline 4 & ${ }^{2 n d}$ weeding & 18 & $18 \times 180=3240.00$ \\
\hline 5 & $3^{\text {rd }}$ weeding & 12 & $12 X 180=2160.00$ \\
\hline 6 & $\begin{array}{l}\text { Thinning, mulching, gapfilling, rouging + Fertilizer application, } \\
\text { Pesticide application + Irrigation }\end{array}$ & 14 & $14 X 180=2520.00$ \\
\hline 7 & Labour for harvesting and carrying (For seed and fibre) & 30 & $30 \times 180=5400.00$ \\
\hline 8 & $\begin{array}{l}\text { Labour required for drying, threshing, cleaning and storing (For } \\
\text { seed) }\end{array}$ & 25 & $25 \times 180=4500.00$ \\
\hline 9 & $\begin{array}{l}\text { Labour required for leaf shattering, retting, fibre drying, cleaning and } \\
\text { storing (For fibre) }\end{array}$ & 35 & $35 \times 180=6300.00$ \\
\hline
\end{tabular}

ii) Material cost:

\begin{tabular}{|c|c|c|c|c|}
\hline Sl & Items & No. of operation & Required amount $/ \mathrm{ha}$ & Total cost (Tk) \\
\hline 1 & Seed rate : & & $4 \mathrm{~kg}(130.00 \mathrm{Tk} / \mathrm{kg})$ & 520.00 \\
\hline \multirow{3}{*}{2} & Fertilizer used: & $180 \mathrm{~kg}(10.00 \mathrm{Tk} / \mathrm{kg})$ & 1800.00 \\
& Urea & & $50 \mathrm{~kg}(22.00 \mathrm{Tk} / \mathrm{kg})$ & 1100.00 \\
& TSP & & $25 \mathrm{~kg}(15.00 \mathrm{Tk} / \mathrm{kg})$ & 375.00 \\
\hline \multirow{3}{*}{3} & Zyp & & $45 \mathrm{~kg}(8.00 \mathrm{Tk} / \mathrm{kg})$ & 360.00 \\
& Fuel required (Diesel) & & $11 \mathrm{~L}$ for $1 \mathrm{plowing}$ & $4 \times 11 \times 62.00=2728.00$ \\
& Plowing (Power tiller) & 4 & $2.5 \mathrm{~L}$ for 1 laddering & $3 \times 2.5 \times 62.00=465.00$ \\
\hline
\end{tabular}

Grand total cost of production seed/ha at direct (line sowing) sowing method $=28980.00+7348.00=36328.00$ Grand total cost of production fibre/ha at direct (line sowing) sowing method $=30780.00+7348.00=38128.00$

Table 3. Cost of seed production per hectare of land following top cutting method at 2012

\section{a) Cost for preparation of mother plant}

Input cost: i) Non-material cost:

\begin{tabular}{|c|c|c|c|}
\hline Sl & Items & Required amount/ha & Total cost (Tk) \\
\hline 1 & Labour cost (Plowing + Laddering) & 13 & $13 \times 180=2340.00$ \\
\hline 2 & Labour cost (Grass cleaning and levelling) & 13 & $13 \times 180=2340.00$ \\
\hline 3 & Labour cost (Lay out prepared + line sowing) & 6 & 6 X180=1080.00 \\
\hline 4 & Labour cost (Broadcasting) & 2 & $2 \times 180=360.00$ \\
\hline 5 & $1^{\text {st }}$ weeding & 25 & $25 \times 180=4500.00$ \\
\hline 6 & ${ }^{2 n d}$ weeding & 15 & $15 \times 180=2700.00$ \\
\hline 7 & $3^{\text {rd }}$ weeding & 12 & $12 \times 180=2160.00$ \\
\hline 8 & $\begin{array}{c}\text { Thinning, gapfilling, rouging + Fertilizer application, Pesticide application } \\
+ \text { Irrigation }\end{array}$ & 12 & $12180=2160.00$ \\
\hline & Total non material cost for mother plant preparation $=\mathbf{1 7 6 4 0 . 0 0}$ & \\
\hline
\end{tabular}


ii) Material cost:

\begin{tabular}{|c|c|c|c|c|}
\hline S1 & Items & No. of operation & Required amount/ha & Total cost (Tk) \\
\hline 1 & Seed rate: & & $6 \mathrm{~kg}(130.00 \mathrm{Tk} / \mathrm{kg})$ & 780.00 \\
\hline 2 & $\begin{array}{c}\text { Fertilizer used: Urea } \\
\text { TSP } \\
\text { MP } \\
\text { Zypsum } \\
\end{array}$ & & $\begin{array}{c}180 \mathrm{~kg}(10.00 \mathrm{Tk} / \mathrm{kg}) \\
50 \mathrm{~kg}(22.00 \mathrm{Tk} / \mathrm{kg}) \\
25 \mathrm{~kg}(15.00 \mathrm{Tk} / \mathrm{kg}) \\
45 \mathrm{~kg}(8.00 \mathrm{Tk} / \mathrm{kg}) \\
\end{array}$ & $\begin{array}{c}1800.00 \\
1100.00 \\
375.00 \\
360.00 \\
\end{array}$ \\
\hline 3 & $\begin{array}{c}\text { Fuel required (Diesel) } \\
\text { Plowing (Power tiller) } \\
\text { Laddering } \\
\end{array}$ & $\begin{array}{l}4 \\
3\end{array}$ & $\begin{array}{l}11 \mathrm{~L} \text { for } 1 \text { plowing } \\
2.5 \mathrm{~L} \text { for } 1 \text { laddering }\end{array}$ & $\begin{array}{l}4 X 11 X 62.00=2728.00 \\
3 \times 2.5 \times 62.00=465.00\end{array}$ \\
\hline \multicolumn{5}{|c|}{ Total non material cost $=\mathbf{7 6 0 8 . 0 0}$} \\
\hline
\end{tabular}

There are three top cutting are produced from 1 plant

Therefore, cost of production of mother plant for one hectare of land $=17640.00+7608.00=25248.00$

\section{b) Cost required for top cutting preparation and transplantation}

Input cost: i) Non-material cost:

\begin{tabular}{|c|c|c|c|}
\hline Sl & Operations & Requirement/ha & Total cost (Tk) \\
\hline 1 & Preparation of top cutting and leave tearing & 35 & $35 \times 180=6300.00$ \\
\hline 2 & Mudding and planting of cuttings & 50 & $50 \times 180=9000.00$ \\
\hline 3 & $1^{\text {st }}$ weeding & 35 & $35 \times 180=6300.00$ \\
\hline 4 & ${ }^{2 n d}$ weeding & 20 & $20 \times 180=3600.00$ \\
\hline 5 & $3^{\text {rd }}$ weeding + Gap filling & 20 & $20 \times 180=3600.00$ \\
\hline 6 & Fertilizer application & 3 & $3 \times 180=540.00$ \\
\hline 7 & Labour for harvesting and carrying & 40 & $40 \times 180=7200.00$ \\
\hline 8 & Labour required for drying, threshing, cleaning and storing & 30 & $30 \times 180=5400.00$ \\
\hline \multicolumn{2}{|r|}{ Total non material cost for top cutting preparation and transplantation $=41940.00$} \\
\hline
\end{tabular}

ii) Material cost:

\begin{tabular}{|c|c|c|c|c|}
\hline Sl & Items & No. of operation & Required amount/ha & Total cost (Tk) \\
\hline \multirow{4}{*}{1} & Fertilizer used: & & $180 \mathrm{~kg}(10.00 \mathrm{Tk} / \mathrm{kg})$ & 1800.00 \\
& Urea & & $50 \mathrm{~kg}(22.00 \mathrm{Tk} / \mathrm{kg})$ & 1100.00 \\
& TSP & $25 \mathrm{~kg}(15.00 \mathrm{Tk} / \mathrm{kg})$ & 375.00 \\
& MP & $45 \mathrm{~kg}(8.00 \mathrm{Tk} / \mathrm{kg})$ & 360.00 \\
\hline \multicolumn{2}{|c|}{ Total material cost for top cutting preparation and transplantation $=3635.00$} \\
\hline
\end{tabular}

Total cost of production for top cutting preparation and transplantation $=41940.00+3635.00=45575.00$

Grand total cost of production of seeds/ha through top cutting method $=25248.00+45575.00=70683.00$

\section{BCR for Seed Production with Seed Treatments and Cuttings Treatments}

Different seed treatments for production of quality healthy jute seeds were based for BCR determination. Cost required f or seed treatment with vitavax-200 and BAU- Bio fungicide for production of seed per hectare were calculated based on market price (Tables 4-5).

Table 4. Cost of seed and fibre production per hectare of land with different seed treatments following line sowing method at 2012

\begin{tabular}{|c|c|c|}
\hline Treatment & Cost of seed production (Tk.) & Cost of fibre production (Tk.) \\
\hline $\mathrm{T}_{1}=$ BAU- Bio fungicide & $36328.00+500=36828.00$ & $38128.00+200=38628.00$ \\
\hline $\mathrm{T}_{2}=$ Provax-200 & $36328.00+1200=37528.00$ & $38128.00+450=39328.00$ \\
\hline $\mathrm{T}_{3}=$ Control & 36328.00 & 38128.00 \\
\hline
\end{tabular}

** Yet BAU- Biofungicide not registered for sale. So price approximately fixed.

Table 5. Cost of seed production per hectare of land with different seed treatments by top cutting method at 2012

\begin{tabular}{|c|c|}
\hline Treatment & Cost of seed production (Tk.) \\
\hline $\mathrm{T}_{1}=$ BAU- Bio fungicide** & $70683.00+500=71183.00$ \\
\hline $\mathrm{T}_{2}=$ Provax-200 & $70683.00+1200=71883.00$ \\
\hline $\mathrm{T}_{3}=$ Control & 70683.00 \\
\hline
\end{tabular}

** Yet BAU- Biofungicide not registered for sale. So price approximately fixed. 


\section{Benefit Cost Ratio (BCR)}

The Benefit Cost Ratio was obtained through gross benefit divided by the total cost using the following formula (2)

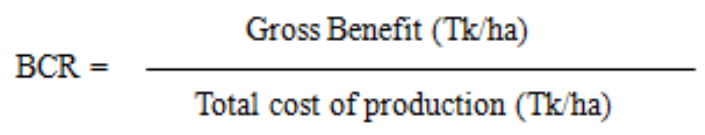

\section{Results}

\section{BCR for Seed and Fibre Production with Different Sowing Methods at JAES and KRS, BJRI}

\section{Seed Production}

The highest seed yield $(585.65 \mathrm{~kg} / \mathrm{ha})$ was recorded in JAES followed by KRS $(569.02 \mathrm{~kg} / \mathrm{ha})$ with top cutting method (Table 6). The lowest seed yield ( $344.50 \mathrm{~kg} / \mathrm{ha}$ ) was recorded in JAES with line sowing method. But BCR was maximum (1.27) in KRS produced with line sowing method followed by JAES (1.23).

Table 6. BCR for seed production of O-9897 with different sowing methods at JAES and KRS, BJRI

\begin{tabular}{|c|c|c|c|c|c|c|}
\hline Location & Sowing methods & Yield $(\mathrm{kg} / \mathrm{ha})$ & $\mathrm{GB}^{1}(\mathrm{Tk} / \mathrm{ha})$ & Cost $(\mathrm{Tk} / \mathrm{ha})$ & NR $(\mathrm{Tk} / \mathrm{ha})$ & $\mathrm{BCR}$ \\
\hline \multirow{2}{*}{ JAES } & $\mathrm{T}_{1}$ & 344.50 & 44785.00 & 36328.00 & 8457.00 & 1.23 \\
& $\mathrm{~T}_{2}$ & 585.65 & 76134.50 & 70683.00 & 5451.50 & 1.08 \\
\hline \multirow{2}{*}{ KRS } & $\mathrm{T}_{1}$ & 354.33 & 46062.90 & 36328.00 & 9734.90 & 1.27 \\
& $\mathrm{~T}_{2}$ & 569.02 & 73972.60 & 70683.00 & 3289.60 & 1.05 \\
\hline
\end{tabular}

Price of O-9897 seed is $130 \mathrm{Tk} / \mathrm{kg}$

$\mathrm{T}_{1}=$ Line sowing, $\mathrm{T}_{2}=$ Top cutting

${ }^{1} \mathrm{~GB}=$ Gross Benefit, NR $=$ Net Return, $\mathrm{BCR}=$ Benefit Cost Ratio

\section{Fibre Production}

Highest fibre yield (3.57 ton/ha) was recorded in JAES followed by KRS (2.97 ton/ha). BCR was maximum (2.16) in JAES (Table 7).

Table 7. BCR for fibre production of O-9897 with line sowing method at JAES and KRS, BJRI

\begin{tabular}{|c|c|c|c|c|c|}
\hline Location & Yield (Ton/ha) & $\mathrm{GB}^{1}(\mathrm{Tk} / \mathrm{ha})$ & Cost $(\mathrm{Tk} / \mathrm{ha})$ & NR $(\mathrm{Tk} / \mathrm{ha})$ & $\mathrm{BCR}$ \\
\hline JAES & 3.57 & 82479.17 & 38128.00 & 44351.17 & 2.16 \\
\hline KRS & 2.97 & 64968.75 & 38128.00 & 26840.75 & 1.70 \\
\hline
\end{tabular}

Price of O-9897 fibre is $925 \mathrm{Tk} / 40 \mathrm{~kg}$ in JAES and O-9897 fibre is $875 \mathrm{Tk} / 40 \mathrm{~kg}$ in KRS

${ }^{1} \mathrm{~GB}=$ Gross Benefit, NR $=$ Net Return, $\mathrm{BCR}=$ Benefit Cost Ratio

\section{BCR for seed and fibre production with Seed Treatments at Different Sowing Methods at JAES and KRS, BJRI}

\section{Line Sowing}

\section{Seed Production}

In this study, seeds were produced with different seed treatments. Maximum seed yield (369.33 kg/ha) was recorded in KRS using BAU- Biofungicide treated seeds (Table 8$)$. The lowest seed yield $(325.52 \mathrm{~kg} / \mathrm{ha}$ ) was recorded in JAES produced with control treatment. BCR was maximum (1.30) in KRS using BAU- Biofungicide treated seeds while minimum BCR at JAES (1.16) was calculated with control treatment.

Table 8. BCR for seed production of O-9897 using different seed treatments at line sowing method at JAES and KRS, BJRI

\begin{tabular}{|c|c|c|c|c|c|c|}
\hline Location & Seed treatment & Yield (kg/ha) & $\mathrm{GB}^{1}(\mathrm{Tk} / \mathrm{ha})$ & Cost (Tk/ha) & NR (Tk/ha) & $\mathrm{BCR}$ \\
\hline \multirow[b]{2}{*}{ JAES } & $\mathrm{T}_{1}$ & 363.98 & 47317.40 & 36828.00 & 10489.40 & 1.28 \\
\hline & $\mathrm{T}_{2}$ & 344.00 & 44720.00 & 37528.00 & 7192.00 & 1.19 \\
\hline \multirow{3}{*}{ KRS } & $\mathrm{T}_{1}$ & 369.33 & 48012.90 & 36828.00 & 11184.90 & 1.30 \\
\hline & $\mathrm{T}_{2}$ & 350.03 & 45503.90 & 37528.00 & 7975.90 & 1.21 \\
\hline & $\mathrm{T}_{3}$ & 343.62 & 44670.60 & 36328.00 & 8342.60 & 1.23 \\
\hline
\end{tabular}

Price of O-9897 seed is $130 \mathrm{Tk} / \mathrm{kg}$

$\mathrm{T}_{1}=$ BAU- Biofungicide $(3 \%$ of seed weight $), \mathrm{T}_{2}=$ Provax $-200 \mathrm{WP}(0.4 \%), \mathrm{T}_{3}=$ Control

${ }^{1} \mathrm{~GB}=$ Gross Benefit, NR $=$ Net Return, $\mathrm{BCR}=$ Benefit Cost Ratio 
Table 9. BCR for fibre production of O-9897 using different seed treatments in line sowing method at JAES and KRS, BJRI

\begin{tabular}{|c|c|c|c|c|cc|c|}
\hline Location & Seed treatment & Yield (Ton/ha) & $\mathrm{GB}^{1}$ (Tk/ha) & Cost (Tk/ha) & NR (Tk/ha) & BCR \\
\hline \multirow{3}{*}{ JAES } & $\mathrm{T}_{1}$ & 4.53 & 104756.25 & 38628.00 & 66128.25 & 2.71 \\
& $\mathrm{~T}_{2}$ & 3.48 & 80475.00 & 39328.00 & 41147.00 & 2.05 \\
& $\mathrm{~T}_{3}$ & 2.69 & 62206.25 & 38128.00 & 24078.25 & 1.63 \\
\hline \multirow{3}{*}{ KRS } & $\mathrm{T}_{1}$ & 3.37 & 73718.75 & 38628.00 & 35090.75 & 1.91 \\
& $\mathrm{~T}_{2}$ & 3.29 & 71968.75 & 39328.00 & 32640.75 & 1.83 \\
& $\mathrm{~T}_{3}$ & 2.25 & 49218.75 & 38128.00 & 11090.75 & 1.29 \\
\hline
\end{tabular}

Price of O-9897 fibre is $925 \mathrm{Tk} / 40 \mathrm{~kg}$ in JAES, and O-9897 fibre is $875 \mathrm{Tk} / 40 \mathrm{~kg}$ in KRS $\mathrm{T}_{1}=$ BAU- Biofungicide ( $3 \%$ of seed weight), $\mathrm{T}_{2}=$ Provax-200 WP $(0.4 \%), \mathrm{T}_{3}=$ Control ${ }^{1} \mathrm{~GB}=$ Gross Benefit, NR $=$ Net Return, $\mathrm{BCR}=$ Benefit Cost Ratio

Table 10. BCR for seed production of O- 9897 using BAU- Biofungicide and Provax 200 in top cutting method at JAES and KRS, BJRI

\begin{tabular}{|c|ccccc|cc|c|}
\hline Location & Seed treatment & Yield $(\mathrm{kg} / \mathrm{ha})$ & $\mathrm{GB}^{1}(\mathrm{Tk} / \mathrm{ha})$ & Cost $(\mathrm{Tk} / \mathrm{ha})$ & NR $(\mathrm{Tk} / \mathrm{ha})$ & $\mathrm{BCR}$ \\
\hline \multirow{3}{*}{ JAES } & $\mathrm{T}_{1}$ & 618.76 & 80438.80 & 71183.00 & 9255.80 & 1.13 \\
& $\mathrm{~T}_{2}$ & 584.80 & 76024.00 & 71883.00 & 4141.00 & 1.06 \\
& $\mathrm{~T}_{3}$ & 553.38 & 71939.40 & 70683.00 & 1256.40 & 1.02 \\
\hline \multirow{3}{*}{ KRS } & $\mathrm{T}_{1}$ & 607.87 & 79023.10 & 71183.00 & 7840.10 & 1.11 \\
& $\mathrm{~T}_{2}$ & 565.05 & 73456.50 & 71883.00 & 1573.50 & 1.02 \\
& $\mathrm{~T}_{3}$ & 534.15 & 72110.25 & 70683.00 & 1427.25 & 1.02 \\
\hline
\end{tabular}

Price of O-9897 seed is $130 \mathrm{Tk} / \mathrm{kg}$

$\mathrm{T}_{1}=$ BAU- Biofungicide ( $3 \%$ of seed weight), $\mathrm{T}_{2}=$ Provax-200 WP $(0.4 \%), \mathrm{T}_{3}=$ Control

${ }^{1} \mathrm{~GB}=$ Gross Benefit, NR = Net Return, $\mathrm{BCR}=$ Benefit Cost Ratio

\section{Fibre Production}

The highest fibre yield (4.53 ton/ha) was recorded in JAES with BAU- Biofungicide treated seeds. The lowest fibre yield (2.25 ton/ha) was recorded in KRS using control treatment. BCR was maximum (2.71) in JAES using BAUBiofungicide treated seeds while the lowest BCR at KRS (1.29) was calculated with control treatment (Table 9).

\section{Top Cutting}

The highest seed yield (618.76 kg/ha) was recorded in JAES using BAU- Biofungicide treated cuttings. The lowest seed yield $(534.15 \mathrm{~kg} / \mathrm{ha})$ was recorded in control treatment at KRS. BCR was maximum (1.13) in JAES using BAUBiofungicide treated cuttings while the lowest BCR at JAES and KRS (1.02) was calculated with control treatment (Table 10). It was evident from the findings that BAU- Biofungicide treated seeds and cuttings produced maximum BCR for seed and fibre production.

\section{Discussion}

Line sowing method had less cost of seed production than top cutting method and encountered with more Benefit Cost Ratio (BCR) than top cutting method. Therefore, it could be concluded that line sowing method was found most suitable in terms of BCR to produce quality healthy jute seeds and fibre production with minimum cost and maximum return. In case of line sowing, for seed production maximum BCR 1.30 was recorded with BAU- Biofungicide treated seeds. The lowest BCR 1.16 was found in control treatment. For fibre production, highest BCR 2.71 was recorded with BAUBiofungicide treated seeds, while the lowest BCR 1.29 was in control treatment. In case of top cutting, highest BCR 1.13 was recorded in BAU- Biofungicide treated cuttings and lowest 1.19 was recorded in control treatment. The findings indicated that BAU- Biofungicide could be used successfully for treating seeds and cuttings. It may be conceived from the present findings that use of seed treatment and cuttings treatment by BAU- Biofungicide in line sowing and top cutting methods produce high quality jute seeds with higher seed yield and highest BCR than that of jute seeds production by other treatments.

\section{Conclusions}

For quality seed and fibre production with maximum BCR from the findings of this study:

- Line sowing method was found most suitable compared to top cutting method for production of quality healthy jute seeds with maximum BCR.

\section{REFERENCES}

[1] BBS, 2011. Statistical Year Book of Bangladesh. Bangladesh Bureau of Statistics, Planning Ministry, Dhaka.

[2] Conyers, D and Hill, P. 1982. An introduction to development planning in the third world. John Wiley \& Sons. Chichester, 
New York, Brisbane, Toranato, Singapore. 138.

[3] Dillon, J. and Hardaker, J. B. 1993. Farm management research for small development. Development of Agricultural Economics and Business Management, University of New England, Armidale, NSW, Australia. 160.

[4] Hossain, I. 2011. BAU- Bio fungicide: Unique eco - friendly means and new dimension of plant disease control in Bangladesh. Lima Printing Press, Mymensingh. 07.

[5] Hossain, M. A.; Talukder, F. A. H.; Islam, M. and Morshed, G. 1994. Studies on $C$. olitorius pipe-line varieties. Ann. Rep. Bangladesh Jute Res. Inst.,Dhaka. 132-137.

[6] IJSG website. 2012-13. www.jute.org

[7] Islam, M. M. 2007. About jute seed research. R.S. printing press, Kalwalapara, Mirpur-1, Dhaka-1216. 1.
[8] Islam, M. M. 2009. Jute seed technology. College gate binding and printing, Dhaka-1207. 1.

[9] Islam, M. M. and Rahman, M. 2008. Hand book on Agricultural technology of jute, kenaf and mesta crops. Bulbul printers, Dhaka-1203. 27-28.

[10] Khandakar, A. L. 1987. Jute seed at farm level. Bangladesh Agric. Res. Coun., Dhaka. 1-77.

[11] Rahman, M.A. 2000. An economic study of banana production in comparison with dominant cropping patterns in a selected area of Jamalpur district. An M.S. thesis in Agricultural Economics Dept. Agril. Econ., BAU, Mymensingh. 54. 